\title{
SZTUKA, POSTSZTUKA, AUTOSZTUKA I ...
}

KAMIL WNUK

twojewnuki@wp.pl

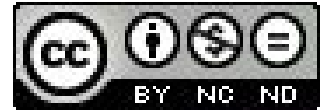

Panie Kamilu, skoro wybiera Pan fotografie,
to najważniejsze jest wszystko to,
co zupetnie nie ma nic z nia wspólnego ${ }^{1}$.

Wszystko zaczęło się od powyższego cytatu. Ale im więcej myślałem o tym, czym są fotografie, tym bardziej stawały się sugestywne i skomplikowane. Fotografia to zarówno pseudoobecność, jak i świadectwo nieobecności. „Fotogeniczne jest tylko to, co daje się gwałcić, zaskakiwać, obnażać, odsłaniać wobec siebie" ${ }^{\prime 2}$. Umiejętności warsztatowe, wyrafinowanie intelektualne zostały zdyskredytowane i wyparte, nie tylko przez monotonne naśladownictwo tego, co było. Co ważniejsze, przez kopiowanie tego, co nie wymaga udawania, że ma się coś, czego się w istocie nie ma. Uważa się zatem, że jest to nieskrępowany popis oraz kpina z tych, dla których sztuka ma jeszcze jakieś znaczenie, jest żałosną próbą publicznego bycia za wszelką cenę w sytuacji, gdy nie ma się do zaoferowania już niczego istotnego. Sugestia ta nasuwa poważne wątpliwości natury etycznej.

Kłopoty z definiowaniem sztuki towarzyszą nam od zarania dziejów. Zdania są podzielone, niektórzy twierdza, że musimy to roztrząsać, by nie dać się ogłupić, zwłaszcza w czasach najnowszych. Dotychczasowe identyfikacje sztuki „ulegają często zniesieniu w wyniku dążenia do wolnej spontanicznej kreatywności i etatowego łamania konwencji, tabu [...] oczywiście pojawia się przy tym mnóstwo zapytań o tym, że artyści podejmują przewrotną i dywersyjną grę przeciwko konwencji”' ${ }^{\prime \prime}$. Celem sztuki staje się dążenie do eliminacji wszystkiego, napiętnowanie wszelkiej niesprawiedliwości. W każdym bądź razie odnaleźć można w tej strategii przykład Fryderyka Nietzschego - artystów tworzących „bez resentymentów i wyrzutów sumienia”, za to z akademickim podręcznikiem marketingu w ręku. Dzieła demaskują wszelkie postawy i często wykraczają poza formy, konwencje sztuki, pozostają bezradne i akceptują taką sytuację. Pojawia się przy tym stwierdzenie, że artyści podejmują przewrotną i dywersyjną grę przeciwko komercji i lansowaniu. Skutek jest dokładnie odwrotny. Powstaje zjawisko postsztuki (forma uczestniczenia w grze o dominację kolejnych kulturowych aktualności. Artefakt postsztuki to spektakl, wydarzenie, produkt), którą można zdefiniować jako to, co wypada, by było sztuką ze względu na jej aktualne uwarunkowania zewnętrzne, czyli dzisiejsze rynkowo-medialne wydarzenia. Jest to zjawisko odmienne od sztuki, kieruje się inną celowościa, innymi środkami. Wyznacza nie tylko negatywne skojarzenia, ale czasem terapeutycznie towarzyszy naszej codzienności, witalizuje i wzmacnia naszą zdolność adaptacji do dzisiejszego stanu sztuki. Cechą główną postsztuki jest „nijakość i symulowanie, symulowanie głębi, mądrości, inteligencji, wrażliwości, dowcipu i talentu. Zamiast poszukiwania głębi czy ważności mamy proste rekontekstualizacje - przekładanie rzeczy i znaczeń w inne miejsca w nadziei, że stanie się coś nowego, że wyjawią

\footnotetext{
1 Dedykacja Jana Berdyszaka z dnia 29.05.2006 r. w katalogu Jan Berdyszak. Skupienie.

J. Baudrillard, Przejrzystość zła, Warszawa 2009, s. 168.

S. Marzec, Sztuka, czyli wszystko. Krajobraz po postmodernizmie, Lublin 2008, s. 135.

Za: L. Ferry, Człowiek - Bóg, Warszawa 1998, s. 23.
} 
one swoje inne aspekty. De facto jest to poszukiwaniem konsternacji widza" ${ }^{\prime 5}$. Wszakże artyści próbują dziś uczestniczyć w grze, starając się sfunkcjonalizować zło, odbierając mu znamiona zła. Jeśli przedstawiciele postsztuki jeszcze mogą irytować, to nie tyle swoimi manifestacjami, co raczej tym, że zgłaszają ciągle jeszcze pretensje do tego, by irytować, poruszać, bulwersować. To, co poraża, nie jest kolejnym krzykiem artysty, wołającego do znudzonych odbiorców, którzy tę scenę widzieli już wiele razy: „Jestem!", ale jego pustka i bezradność. Gdy z lekceważącą wyższością mówią pogardliwie o społecznych konwenansach, którym, jak sądzą nie ulegaja, nie dostrzegają faktu, że ich postawa buntu i dezynwoltury jest w rzeczywistości jedynie zamianą jednego wariantu stylu życia na inny, jednej maski społecznego teatru na inna, bo wbrew ich postmodernistycznym marzeniom o unicestwieniu kultury, czyli formy, nie ma od niej ucieczki. I mimo, iż postsztuka to symulowanie, pomimo, że postulowana jest jako aktualna, „pozostaje bez związku z jakąkolwiek rzeczywistością: jest czystym symulakrem samego siebie. [...] obraz nie należy już do porządku pozorów, lecz do dziedziny symulacij" ${ }^{\prime \prime}$. Również w obrębie sztuki czy technologii mamy do czynienia ze swoistymi klonami, które mogą być wytworzone w teoretycznie nieskończonej liczbie, „,rzeczywistośćjest produkowana przez mikroskopijne komórki, matryce i moduły pamięci, systemy operacyjne - da się ją zatem powielać w nieskończonośćn ${ }^{\prime \prime 7}$. Pojęcie simulacrum ewoluowało $\mathrm{w}$ XXI wieku w postaci reality TV czy też poprzez strony internetowe, przedstawiające „prawdziwe życie”. Simulacrum jest zatem doskonałą reprodukcja, repliką niczym nie różniącą się od oryginału, jest obecnością pozoru. Rodzi to rzecz jasna niebezpieczeństwo, iż symulacja maskuje różnice między tym, co prawdziwe, a tym, co fałszywe. Wszystko ulega zmienności i jest niestabilne. W oczywisty sposób wpływa to na nasz brak wiary i dopuszczenie w każdej sferze naszego życia pewnego poziomu domniemywań czy supozycji. „Tak więc, co widzisz, to właśnie otrzymasz, ale nigdy nie otrzymasz tego, czego nie powinieneś zobaczyć i nigdy nie będziesz pewny, czy dar pochodzi z rzeczywistości"8. Owo odrealnienie, dzięki tak skutecznemu zastosowaniu zasady performatywnej, jest obecne już wszędzie. Pomimo tego, że jesteśmy świadomi, iż obrazy mogą być oszustwem, nadal im ulegamy. Według Jeana Baudrillarda świat symulakrów jest wytworem naszej rozpaczliwej i żarłocznej pogoni za rzeczywistością - za prawda, tożsamościa, pojęciem, jasnością. Dążąc do absolutnej pewności, skroiliśmy świat skrajnie niepewny. Zwyczajnie zgadzamy się na konsekwencje zmian naszego pojmowania realności i podążamy drogą odrealnienia. Konsekwencją odrealnienia jest, zdaniem Wolfganga Welscha, indyferencja, a więc postawa obojętności i bierności wobec wszechobecnych symulacji. Proces ten jednak niewątpliwie otwiera drogę ku coraz to większej wolności człowieka. W tego rodzaju rzeczywistości medialnej, wirtualnej, elektronicznej, aby powrócić do siebie - aby odzyskać własną tożsamość, pewność, pojęcie samego siebie, odniesienie do rzeczywistości - trzeba posłużyć się przemocą. Albo inaczej: każde ustanowienie samego siebie poza istniejącym porządkiem symulakrów, wbrew temu porządkowi, staje się przemocą . „Istotą dojrzałości jest, jak sądzę, poczucie własnej tożsamości, jednostkowości, tego, że ostatecznie jest się samemu przeciwko całemu światu"9. Nie można bowiem inaczej upomnieć się o własną

S. Marzec, Sztuka..., dz. cyt., s. 136.

J. Baudrillard, Symulakry i symulacja, Warszawa 2005, s. 11-12.

Tenże, Precesja symulakrów, Kraków 1998, s. 176

A. Zeidler-Janiszewska (red.), Problemy ponowoczesnej pluralizacji kultury. Wokót koncepcji Wolfganga Welscha, Poznań 1998, s. 91.

9 D. Wodecka, J. Dehnel, Cały jestem przywiazaniem, http://wyborcza.pl/1,76842,7629956,Dehnel_Caly_jestem_ przywiazaniem. $\mathrm{html}$ ?as=1\&starasz $=\mathrm{x}, 5.03 .2010$.

82

OgRODY NAUK I SZTUK 
tożsamość. To, co oferuje nam współczesny świat, jest upokarzającym darem. W jednej chwili otrzymujemy od tego świata wszystko - naszą tożsamość, biografię, porządki marzeń i spełnien. $\mathrm{W}$ pakiecie promocyjnym rzeczywistość jest zawsze na miarę naszych oczekiwań, a w razie reklamacji producent zwraca różnicę. Żyjemy zatem wszyscy we wszechświecie osobliwie podobnym do oryginału - rzeczy są w nim dublowane przez scenariusz tych rzeczy. Świat stworzony w imię uznania każdej odrębności, pożera wszelką indywidualność, zwracając ją pod postacią symulakrum - naszej podmiotowości podrobionej.

Żyjemy w „społeczeństwie spektaklu”, który znosi wszelkie dystanse, zahamowania oraz neguje sfery prywatne i publiczne. Wynika to z kultury nadmiaru i oznacza kryzys sceny, $\mathrm{w}$ tym podziału na aktorów i widzów, oznacza to redukcję do tego, co widzialne. Baudrillard definiuje obsceniczność jako „wszystko to, czego widzialność pozbawiona jest celu, konieczności, pragnienia i skutku"10. To także efekt niepowstrzymanego rozumienia sztuki (myśl ludzka zaczyna się borykać z problemem konfliktu interpretacji. Ów pat zaczyna być tak istotny i znaczący, że nie dotyczy już spraw ogólnych, zwiastujących, ale niemożliwości dogadywania (się) człowieka z człowiekiem w sprawach codziennych. Człowiek przestał argumentować swoje przekonania, już nie odnosi ich do norm, regut, kanonów. Nie tylko się z nimi nie zgadza, ale funkcjonuje w kompletnej abstrakcji wobec nich), przed którą bronić mogą się tylko pozory jako formuła symulacji. W tym kontekście sztuka traci pragnienie złudzenia, co potwierdza przekonanie Nietzschego, że „wraz ze światem realnym obaliliśmy także świat pozorny”"11. Dziś artyści próbują poprzez obscenę (wszak w łacinie obscenus oznacza złą wróżbę) wyrazić okrucieństwa i bóle świata, ale widzowie przyswajają to jako kolejną niezobowiązującą formę rozrywki.

Charles Baudelaire lansował figurę dandysa tworzącego coś radykalnie nowego, niestylizującego się, ale próbującego wynaleźć siebie. Kontynuacją dandyzmu jest kultura kampu (to sztuczność, przesada, połączenia operowości i baletowości, mająca na celu kształtowanie ciała, a nie wydobywanie piękna). Kamp jest to przesada i brzydota, ale ta niewinna i niezamierzona. Jest także dystansem wobec kultury masowej. Wystylizowana wystawa, wykwintność żartu i ironia ideologii wartościowania zawłaszcza uwagę i szacunek innych. Kontynuacją tej tradycji jest dzisiejszy styl glamour, jego błyszcząca świadomość idoli i gwiazd. Dziś, raczej bezrefleksyjnie i automatycznie, utożsamia się z prowokacją czy autentyzmem, nie zauważając, że jest to realizacja zapotrzebowania massmedialnej logiki jako „zarazy, plagi mścicielskiej, w którym życie poddawane jest torturom, zdeptaniu i przekracza wszelkie granice"12.

Szok powstaje, gdy bodźce zewnętrzne nie są asymilowane w doświadczenia, następuje wówczas zawieszenie, zablokowanie. Jednak szok domaga się odpowiedzi, wymusza reakcję na innym poziomie wrażliwości i światopoglądu. Stąd też nie wypada żywić nadziei, że szokując osiagniemy określony skutek. O doskonałym przykładzie wstrząsu jak pisze Jacques Ranciere: „,hodzi o to, by kierować szokiem, inscenizować obcość tego, co swojskie, pokazywać innym porządek miary, który można odkryć tylko dzięki przemocy konfliktu"13.

Czas najwyższy porzucić kontemplowanie drogowskazów i ruszyć wreszcie w drogę. Cytowany powyżej Sławomir Marzec obawia się, że „bycie artysta, a nawet skandalizującym postartysta, nie zwalnia nas z obowiązku bycia człowiekiem dbającym o jakość własnych myśli, uczuć, uwagi etc. oraz ich optymalnej korelacji. Sztuka, a zwłaszcza hasło postępu sztuki nie może być

10 J. Baudrillard, Pakt jasności, Warszawa 2005, s. 78.

11 Za: P. Markowski, Postmodernizm - teksty polskich autorów, Kraków 2003, s. 86.

U. Eco (red.), Historia brzydoty, Poznań 2007, s. 436.

J. Ranciere, Estetyka jako polityka, Warszawa 2007, s. 83. 
alibi dla tandety"14. Jednak o tym, czego dowiedziałem się o nauczaniu w całym tym odpychającym trzęsawisku, można powiedzieć wszystko, ale nie to, że jest nieistotne. Nawet w najmniej sprzyjających warunkach pod względem psychologicznym, finansowym, edukacyjnym - wciąż odnosimy sukcesy. Moim zdaniem, eksperymenty w poczuciu istnienia możliwej drogi twórczej przeprowadzą przez kulturę, nawet jeżeli ta kultura wydaje się ślepo samopowielać.

Niełatwo zmienić sposoby działania, gdy ulegają instytucjonalizacji nie tylko w sensie prawnym, ale także w przyzwyczajeniach tych, którzy stali się nieświadomie zbyt zależni od silniej osadzonych procedur prawnych. Jak zasada precedensu, dostarczana naszej kulturze. To nieuchronnie włączy nas w niekończącą się ocenę dopasowania tego, co dana kultura uznaje za niezbędne dla dobrego, pożytecznego lub godnego stylu życia, do sposobów, w jakie jednostki dostosowują się do wymagań. Wszystkie te sprawy mają bezpośredni związek z tym, w jaki sposób kultura lub społeczeństwo zawiadują swoim systemem edukacji. Edukacja stanowi bowiem podstawowe ucieleśnienie życia $\mathrm{w}$ kulturze, a nie jedynie przygotowanie do niego. Co więcej, przyswojona wiedza najbardziej przydaje się do odkryć w obrębie własnych wysiłków poznawczych. Jest bowiem powiązana z tym i używana w odniesieniu do tego, co już wcześniej wiedzieliśmy. Umysł znajduje się w głowie, ale także w interakcji z innymi. Nauczenie się technik wspomagających używanie umysłu, łączenie z zastosowaniami technologii dla rozszerzenia własnych zdolności. Nauczenie się by dokonywać refleksji i z łatwością docierać do sedna posiadanej wiedzy, by przekazaćją innym, a później samemu zrobić z niej użytek. Przyswojenie sobie też wyrazistego wyobrażenia o tym, jak może wyglądać kultura uczenia się. Oczywiście żyjemy w czasach, w których „nietolerancyjny pluralizm metody naukowej rozpoznany został jako nie mniej ideologicznie ograniczający"15.

Żaden rozsądny człowiek nie mógłby zaprzeczyć, że metody naukowe kolosalnie zwiększyły ludzkie zdolności do przewidywania i kontrolowania własnego środowiska. Chwilowe wrażenie, niemal szokujące - tu i teraz. Czyż nie ten właśnie efekt powinna naśladować nowoczesna sztuka? Przeżycie. Przeżycie związane z masą bodźców, których nie jesteśmy w stanie zintegrować. Przeżycie, które staje się nieustannym szokiem, zadziwieniem. Tego właśnie musi dostarczyć nam artysta - szoku, który wyrwie nas z doświadczenia - przeżycia. W przeciwnym razie jego twórczość nie ma dużych szans wpłynąć na potencjalnego widza. Świadomość widza nie jest już w stanie doświadczać. Potrafi przeżywać - i artysta powinien być świadom tego faktu. To, co mam na myśli, pozwolę sobie przywołać słowami Jana Berdyszaka: „znaczący artyści byli zawsze ludźmi bardzo świadomymi. Jedni byli świadomi z powodu wiedzy, inni byli bardzo świadomi z powodu intuicji" ${ }^{\prime 16}$. Wszystko, co czynimy, wpływa na jej kształt. Sukcesem staje się autentyzm, który nie pozwala nam stawać się innymi lepszymi i budować siebie na własną odpowiedzialność.

„Skoro świat obrał kurs na szaleństwo, winniśmy za jego przykładem ujrzeć go z szaleńczej perspektywy"17. Po jakimś czasie oczywiście czarne okazuje się białym i na odwrót, czyli okazuje się, że nic właściwie się nie zmieniło. Nie wiem, czy jest to argument przemawiający za twierdzeniem, iż potrzeba złudzeń jest silniejsza od potrzeby prawdy.

Konfrontacja jest silnym, lecz ryzykownym lekiem na nieświadomość. Jej składnikiem jest zawiedzione oczekiwanie, odkrycie, że nasza wersja rzeczywistości pozostaje w sprzeczności

14 S. Marzec, Sztuka..., dz. cyt., s. 184.

15 J. Bruner, Kultura edukacji, Kraków 2006, s. 207.

16 M. Wasilewski, Sztuka nieobecna, Poznań 1999, s. 77.

17 J. Baudrillard, Pakt..., dz. cyt., s. 5. 
z tym, co następnie okazuje się prawdą. Konfrontacja może wszakże wymagać rozsądzenia, jak podczas zawierania ugody przez strony przeciwne. W rzeczywistości zachodzi większe prawdopodobieństwo, że konfrontacja wzbudzi gniew i oburzenie, aniżeli podniesie świadomość. Nadal dominuje przyjęty punkt widzenia i nic nie zapowiada, zwłaszcza w Polsce, by poza recytowaną ideologia, coś się zmieniło. Niektórzy, twierdzą że „oczywiście ciemnota krajowa nie jest mała i mamy się czym na tym gruncie pochwalić. Niedorzeczna jednak jest nadzieja, że masa wstrząsana, prowokowana, poniżana, potępiana czy wyśmiewana, ugnie się, zamieni w rozbawioną czeredę yappi'sów"18. W najlepszym przypadku zbulwersowana publiczność stwierdza z fałszywą kurtuazja, że współczesnej sztuki nie rozumie, więc co za tym idzie, sztuka ta pozbawiona jest znaczenia i poświęcenie jej czasu i uwagi nie ma większego sensu. Anda Rottenberg stwierdziła w jednym z wywiadów, że „do galerii zaczęły chodzić grupy osób nie po to, by ze sztuką obcować, ale żeby szukać wykroczeń przeciwko swojemu światopoglądowi"19. Zaczyna liczyć się tylko intesywność poruszeń. Bowiem nie możemy przewidzieć reakcji innych ludzi do końca, część się tylko oburzy, część potraktuje to jako nową formułę rozrywki, a tylko nieliczni zaczną snuć własne refleksje. Mimo wszystko, trzeba zachować zdolność oburzenia się. „Kompletnie nagi, młody mężczyzna w towarzystwie ekipy filmowej pojawił się podczas porannej mszy w wejściu do łódzkiej katedry. Wierni i proboszcz są zszokowani i obrażeni. To tylko sztuka - odpowiada prof. Marek Wasilewski, reżyser performance'u' ${ }^{\prime 20}$. Wszystko co spektakularne, frywolne, ulotne i błyszczące, a co widzimy w coraz większym stopniu w mediach, wnika także do obszaru kultury i sztuki. A zatem bycie dobrym w biznesie jest najbardziej fascynującym rodzajem sztuki. Fakty pokazuja, że sztuka jest w stanie nie tylko przeżyć swą wielokrotną śmierć, ale nawet z powodzeniem się nią karmić. „Prowokacją jest dopiero podpis i informacja, jak rzecz została zrobiona" ${ }^{21}$. Zapisy fotograficzne dostarczają dowodów rzeczowych. Coś, o czymś słyszeliśmy i w co wątpimy, wygląda na dowiedzione, jeśli pokażemy to na zdjęciu. W jednym ze swoich praktycznych zastosowań zapis fotograficzny stanowi zatem dowód obciążający. Zdjęcie może zniekształcać, ale zawsze zakładamy, że coś, co oglądamy, istnieje albo istniało. „Fotogeniczne jest bowiem tylko to, co nieludzkie. Dzięki temu możliwe jest wzajemne oszołomienie, a tym samym stworzenie więzi człowieka ze światem, a świata z naszym spojrzeniem"22.

Odbiór sztuki nie wymaga żadnej specjalnej wiedzy ani żadnego specjalnego przygotowania, każdy może czerpać radość z kontaktu ze sztuka, jeśli tylko chce. Sztuka jest sprawą przeżyć i doświadczeń a nie wiedzy, która zabija naturalną przyjemność obcowania ze sztuką. Celem sztuki staje się dążenie do eliminacji wszystkiego. W zdumienie wprawia fakt, iż „nie jesteśmy od rozumienia rzeczywistości, lecz tylko od jej wypowiadania - że my, sztuka, jesteśmy rzeczywistością. Sztuka to fakt, a nie komentarz doczepiony do faktu. (...) Jesteśmy słowem, które stwierdza: to boli - to mnie zachwyca - to lubię - tego nienawidzę - tego pożądam - tego nie chcę"23. Za pośrednictwem ekranów, fotografii i wideo możemy dzisiaj ujrzeć jedynie to, co przed nami zobaczyli już inni. Wszystko zdaje się tak proste i oczywiste, że nawet ten, kto podąża za tym obliczem, naraża się na zarzut, przekraczania statusu artysty. Zatem artysta ma być

\footnotetext{
18 S. Marzec, Sztuka..., dz. cyt., s. 146

A. Leszczyński, Cenzura obroną przed innościa?, http://wyborcza.pl/1,78302,3838234.html, 9.01.2007.

20 M. Witkowska, Wbiegł nago na msze do katedry, http://dzienniklodzki.pl/wiadomosci/256105,lodz-wbiegl-nadona-msze-do-katedry,id,t.html, 15.05.2010.

21 S. Szabłowski, Brooklyński barok Andresa Serrano, „Machina” 1998, nr 6, s. 82.

22 J. Baudrillard, Pakt..., dz. cyt., s. 169.

23 W. Gombrowicz, Dziennik 1957-1961, t. 2, Kraków 1997, s. 79.
} 
w tej perspektywie sobąi owo bycie sobą wyrażać, dając swoją aktywność i biografię. Tam, gdzie inni upatrują (post)artystę jako człowieka, który „gnuśnieje w swojej sprytnej interesowności, zamknięty w getcie swoich wyobrażeń i nawyków" ${ }^{\prime 24}$. W gruncie rzeczy szybciej robią kariery, doskonale poruszają się po rynku sztuki, cenią się, również finansowo. Jeśli chodzi o część należącą do mnie to „doświadczenie osobiste, jakie wykorzystałem, nie mieści się w konkretnej historii. Są to stany, ruchy, skrzywienia, pochodzące z wielu poprzednich doświadczeń. Jest jednak - czemu o tym nie wspomnieć? - jeden epizod krystalizujący. Powiedzmy, że obmyśliłem tą książkę jako sposób na to, by się nie zgubić, by nie zatracić się w rozpaczy"25. Oficjalnego przedsięwzięcia edukacyjnego „,co dzięki długotrwałemu obcowaniu z dziełem tak dobrze przyswoili sobie język, że posługują się nim tak, jakby to był ich własny język. Gdy słuchamy tych wirtuozów, niekiedy tylko nasuwa się nam pytanie, czy przypadkiem nie biorą oni za zrozumienie doktryny tego, co jest jedynie łatwością mówienia o niej"26.

Od słowa do słowa tracę siły (...)

Jeśli pozwolisz mi usłyszeć - zapomnę; jeśli pozwolisz mi zobaczyć - zapamiętam; jeśli pozwolisz mi zrobić - zrozumiem

\section{Lao Tsy}

\section{BIBLIOGRAFIA}

Baudrillard J., Pakt jasności, Warszawa 2005.

Baudrillard J., Precesja symulakrów, Kraków 1998.

Baudrillard J., Przejrzystość zła, Warszawa 2009.

Baudrillard J., Symulakry i symulacja, Warszawa 2005.

Barthes R., Fragmenty dyskursu mitosnego, Warszawa 1999.

Betting H., Antropologia obrazu. Szkice do nauki o obrazie, Kraków 2007.

Bruner J., Kultura edukacii, Kraków 2006.

Dziamski G., Sztuka po końcu sztuki. Sztuka początku XXI wieku, Poznań 2009.

Eco U. (red.), Historia brzydoty, Poznań 2007.

Ferry L., Człowiek - Bóg, Warszawa 1998.

Gombrowicz W., Dziennik 1957-1961, t. 2, Kraków 1997.

Gilson E., Byt i istota, Warszawa 1963.

Kuspit D., Koniec sztuki, Gdańsk 2006.

Markowski P., Postmodernizm - teksty polskich autorów, Kraków 2003.

Marzec S., Sztuka, czyli wszystko. Krajobraz po postmodernizmie, Lublin 2008.

Pareyson L., Estetyka. Teoria formatywności, Kraków 2009.

Ranciere J., Estetyka jako polityka, Warszawa 2007.

Rouille A., Fotografia. Między dokumentem a sztuką wspótczesna, Kraków 2007.

Schechner R., Performatyka. Wstęp, Wrocław 2006.

Scruton R., Przewodnik po kulturze nowoczesnej, Łódź 2006.

Soulages F., Estetyka fotografii. Strata i zysk, Kraków 2007.

Stlegier B., Obrazy Fotografii. Album metafor fotograficznych, Kraków 2009.

Szabłowski S., Brooklyński barok Andresa Serrano, ",Machina” 1998, nr 6.

Wasilewski M., Czy sztuka jest wściektym psem?, Poznań 2009.

Wasilewski M., Sztuka nieobecna, Poznań 1999.

Zeidler-Janiszewska A. (red.), Problemy ponowoczesnej pluralizacji kultury. Wokót koncepcji Wolfganga Welscha, Poznań 1998.

\section{Netografia}

24 S. Marzec, Sztuka..., dz. cyt., s. 193.

25 R. Barthes, Fragmenty dyskursu mitosnego, Warszawa 1999, s. 30.

26 E. Gilson, Byt i istota, Warszawa 1963, s. 319. 
Leszczyński A., Cenzura obroną przed innością?,

http://wyborcza.pl/1,78302,3838234.html, 9.01.2007.

Witkowska M., Wbiegł nago na msze do katedry, http://dzienniklodzki.pl/wiadomosci/256105,lodz-wbiegl-nado-na-mszedo-katedry,id,t.html, 15.05.2010.

D. Wodecka, J. Dehnel, Cały jestem przywiazaniem, http://wyborcza.pl/1,76842,7629956,Dehnel_Caly_jestem_przywiazaniem. html?as=1\&starasz $=x, 5.03 .2010$.

\section{Słowa kluczowe}

sztuka, postsztuka, symulakrum, postmodernizm

\section{STRESZCZENIE}

Celem sztuki staje się dążenie do eliminacji wszystkiego, napiętnowanie wszelkiej niesprawiedliwości. Dzieła demaskują wszelkie postawy i często wykraczają poza formy, konwencje sztuki, pozostają bezradne i akceptują taką sytuację. Pojawia się przy tym stwierdzenie,

że artyści podejmują przewrotną i dywersyjną grę przeciwko komercji i lansowaniu. Skutek jest dokładnie odwrotny. Powstaje zjawisko postsztuki (forma uczestniczenia w grze o dominację kolejnych kulturowych aktualności. Artefakt postsztuki to spektakl, wydarzenie, produkt), którą można zdefiniować jako to, co wypada, by było sztuką ze względu na jej aktualne uwarunkowania zewnętrzne, czyli dzisiejsze rynkowo-medialne wydarzenia. Jest to zjawisko odmienne od sztuki, kieruje się inną celowością, innymi środkami.

\section{ART, POSTART, AUTOART AND...}

\section{Keywords}

art, postart, postmodernism

\section{Summary}

The purpose of art is to aim at eliminating everything, branding injustice. The art works uncover al attitudes and often cross the forms and conventions, become helpless and accept such situation. Artists are said to play a diversionary game against lancing and commercialisation. But the result is completely opposite. The phenomenon of postart appears (the form of participation in a game for domination of following cultural actualities. Postart artifact are: events, performance, products). Postart can be defined as that what must be called art because of market trends. It is a different phenomenon than art, which follows different rules and methods. 